\title{
The Use of Production-based Learning Models to Improve Student Learning Outcomes in the Study of Carving Working Techniques on Skill Competence
}

\section{Entin T. Agustina ${ }^{1,2}$}

${ }^{1}$ Vocational Education Program (extraordinary lecturer in family welfare education study program) Family Welfare Education Department, Indonesian Education University, Bandung, Indonesia

${ }^{2}$ Teacher of SMK 14 Bandung

\section{Abstract}

This research was carried out in two cycles. Data were obtained through observations using observation sheets, questionnaires, and tests. The results of the study show an increase in learning outcomes at the end of the cycle. From cycle I which reached the classical completeness $36.67 \%$ increased to $90.32 \%$. The results of observations

Corresponding Author: Entin T. Agustina dretinagustina@gmail.com

Received: 11 January 2019 Accepted: 14 February 2019 Published: 25 March 2019

Publishing services provided by Knowledge E

(c) Entin T. Agustina. This article is distributed under the terms of the Creative Commons

Attribution License, which permits unrestricted use and redistribution provided that the original author and source are credited.

Selection and Peer-review under the responsibility of the 3rd ICTVET 2018 Conference Committee.

\section{G OPEN ACCESS} on the activities of students' activities during the learning process also showed an increase of 60.27 scores in the first cycle with the category quite active and 97 at the second meeting or cycle with a very high category. For the observation activities, teacher activities in cycle I became 67 with the category of ckup and in the second cycle it increased by a very high category with a score of 99 . This proves that the production-based learning model can improve learning outcomes.

Keywords: production-based learning, learning outcomes, carving work techniques

\section{Introduction}

Learning achievement achieved by students can be influenced by two factors, namely internal and external factors [1]. The main causes of learning disabilities are internal factors, including interest, talent, motivation, intelligence level, while the main causes of learning problems are external factors, among others in the form of incorrect learning models and strategies, management of learning activities that do not arouse learning motivation of students, as well as environmental factors that are very influential on the learning achievement achieved by students.

During this time, a number of obstacles were faced in relation to how to create interactive learning situations in the Carved Work Engineering subjects in Creative Wood 
and Rattan Craft Skills Competencies at State Vocational High School 14 Bandung. If students are not active and creative, it will have an impact on understanding that is limited to knowledge. The lack of level of understanding and creativity of students in the Carving Work Technique subject has an impact on the low learning achievement achieved. Even though the desire and interest of students to work in the Business World or Industrial World after attending school is very high.

\section{Methods and Equipment}

\subsection{Methods}

\subsubsection{Diagrammatic representation}

This research is an action research (action research) which aims to Enhancing result learn learners through observation of the activities of teachers and learners in the subjects of carving work techniques in competency skills wood and rattan craft at State Vocational High School 14 Bandung. Actions taken are observations of teachers and students during the learning process in the classroom. Type The selected action research is a kind of emancipatory. Type this emancipatory considered the most appropriate for this study was conducted to address the problem the working area of the researchers themselves based on everyday experience. With In other words, based on observation, self-reflection, the teacher is willing to do changes so that its performance as an educator will be amended is increased. The design of the study is a model design Kemmis and Taggart consisting of four steps, namely: planning, implementation, observation and reflection Figure 1 [2]. This model was chosen because of the learning always begins with the planning, implementation, observation and reflection. In this study will be conducted in two cycles, and step-steps in each cycle includes planning, action, observation, and reflection.

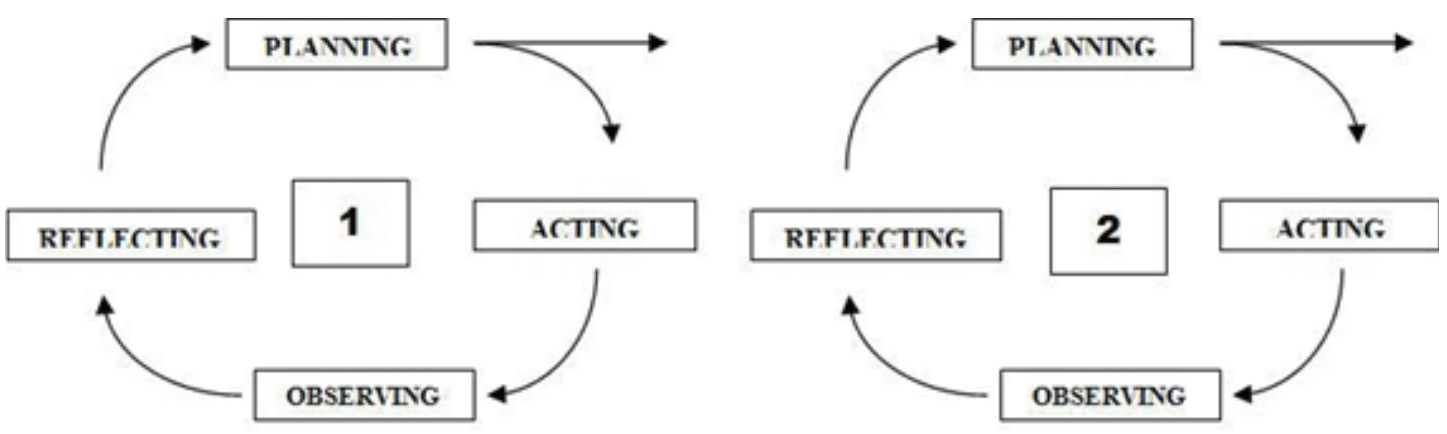

Figure 1: The design of the study is a model design Kemmis and Taggart. 


\section{Results}

Based on the data from the research cycle l about the learning outcomes in the subjects of carving work techniques with basic competencies to make products with deep carving work techniques using the Production Based Learning model obtained data for the highest value obtained by respondents was 7.83 , the lowest value is 31.25 , and the average learning achievement of learning techniques of carving with basic competencies makes the product with deep carving work techniques by 56.70 with learning completeness by $58.06 \%$.

This classroom action research was carried out with the aim of improving the learning outcomes of class XI students of creative wood craft skills packages at State Vocational High School 14 Bandung on the subjects of carving work techniques with basic competencies making products with deep carving work techniques with a Production Based Learning model. From the results of the analysis carried out in cycle I, the results of the analysis obtained are far from encouraging because both the average score and the level of completeness obtained by students in a classical way is still far enough from the standard of learning success that is 70 with $90 \%$ completeness. Meanwhile, the average score obtained by students in this cycle is 56.88 with $36.67 \%$ completeness. From the results of reflection I obtained it is still far from encouraging because both the average score and the level of completeness obtained by students in a classical way are still far enough from the standard of learning success that is determined then the implementation of action II.

TABLE 1: Cycle I.

\begin{tabular}{|c|c|c|c|}
\hline Interval & Frequency & Percentage & Results \\
\hline $100-91$ & 0 & $0 \%$ & Competent \\
\hline $90-81$ & 0 & $0 \%$ & Competent \\
\hline $80-71$ & 11 & $35.48 \%$ & Competent \\
\hline $70-61$ & 7 & $22.58 \%$ & Competent \\
\hline $60-51$ & 5 & $16.13 \%$ & Not Competent \\
\hline $50-41$ & 2 & $6.45 \%$ & Not Competent \\
\hline $40-31$ & 6 & $19.35 \%$ & Not Competent \\
\hline$<30$ & 0 & $0.00 \%$ & Not Competent \\
\hline Score & $\mathbf{3 1}$ & $\mathbf{1 0 0 , 0 0 \%}$ & \\
\hline
\end{tabular}

Based on data from the research cycle II results about the learning achievement of carving work engineering subjects with basic competencies to make products with deep carving work techniques with a Production Based Learning model obtained data for the highest value obtained by respondents is 96.67 and the lowest value amounting 
to 53.25 , it can be read in full on the classified frequency distribution table according to learning achievement categories of carved work engineering subjects with basic competencies making products with deep carving work techniques with a Production Based Learning model.

The average learning achievement learning subjects of carving work techniques with basic competencies make products with deep carving work techniques in Cycle II through the Production Based Learning model of 81.09 and individual completeness reaches $90.32 \%$. Portrait of learning carving work engineering subjects with basic competencies to make products with deep carving work techniques have achieved the objectives set out in learning completeness, namely 70 of the total number of students in the class have achieved individual learning completeness, so classroom action research is stated succeed, and do not need to take the next action.

TABLE 2: Cycle II.

\begin{tabular}{|l|c|c|c|}
\hline Interval & Frequency & Percentage & Results \\
\hline $100-91$ & 20 & $64.52 \%$ & Competent \\
\hline $90-81$ & 5 & $16.13 \%$ & Competent \\
\hline $80-71$ & 3 & $9.68 \%$ & Competent \\
\hline $70-61$ & 2 & $6.45 \%$ & Not Competent \\
\hline $60-51$ & 1 & $3.23 \%$ & Not Competent \\
\hline $50-41$ & 0 & $0.00 \%$ & Not Competent \\
\hline $40-31$ & 0 & $0.00 \%$ & Not Competent \\
\hline$<30$ & 0 & $0.00 \%$ & Not Competent \\
\hline Score & 31 & $100 \%$ & \\
\hline
\end{tabular}

\section{Discussion}

The occurrence of the action hypothesis in this study proves that the application of the Production Based Learning model can improve student learning outcomes. Besides the cognitive aspects of students, the application of the model is also able to improve the affective and psychomotor aspects. Affective aspects that appear are sincerity, courage, while psychomotor aspects can be seen from the speed and accuracy of students completing a series of tasks. In learning in the classroom the teacher uses the Production Based Learning model is one of the teacher's efforts in learning innovation in the subjects of carving work techniques with the basic competencies of making products with deep carving work techniques. The researcher realizes that the learning that has been done is still experiencing obstacles and less effective and has not been able to reflect a success in learning so that it needs to be followed up to find out the 
cause. The problem solving of learning in the 3rd semester carving work technique subjects on Creative Wood and Rattan Craft Skills Competencies in State Vocational High School 14 Bandung in the form of low student learning outcomes can be done through Classroom Action Research.

\section{Conclusion}

The learning process must be able to equip students with abilities that enable them to face and solve problems in their lives in the future. Meanwhile, learning conducted in schools tends to be only as a transfer of information and knowledge provided by the teacher as the dominant factor. One approach to learning that can be done is Production Based Learning. Production Based

Learning focuses more on learners as learners and on issues that are authentic and relevant to be solved using all the knowledge they have or also from other sources. With the Production Based Learning model students are required to be able to work in groups to achieve shared results. Production Based Learning starts from defining problems, then students conduct discussions to equalize perceptions about problems and set goals and targets to be achieved. After that students look for materials from other sources such as from the library, internet, or through personal interviews or observations. Based on the results of research on improving student learning achievement through the application of the Production Based Learning model in cycle I and cycle II it can be concluded that the application of the Production Based Learning model can improve the learning achievement of class XI students of creative craft design and production skills State Vocational High School 14 Bandung on the learning of carved work engineering subjects with basic competencies to make products with deep carving work techniques

\section{Funding}

This work was supported by personal funds.

\section{Acknowledgement}

The authors would like to thank their colleague for their contribution and support to the research. They are also thankful to all the reviewers who gave their valuable inputs to the manuscript and helped in completing the paper. 


\section{Conflict of Interest}

The authors have no conflict of interest to declare.

\section{References}

[1] Sudjana, N. (2006). Assessment of the results of the teaching and learning process. Bandung: PT Remaja Rosdakarya.

[2] Arikunto, Suharsimi. (2013). Research Procedure A Practical Approach. Jakarta: Rineka. 